\title{
表現における基碮连動の指革に関する研究 II
}

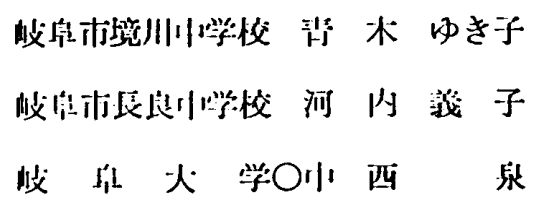

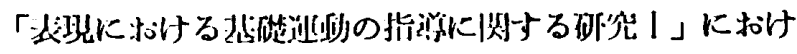

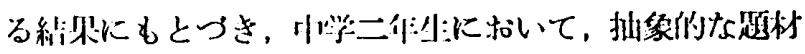

芯えらび，二つのう沙で比恔した。

\section{実矣の方法}

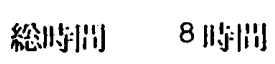

刘像 |兴校二儌: 86 多

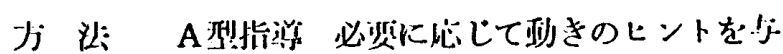

$$
\text { えた埸合 }
$$

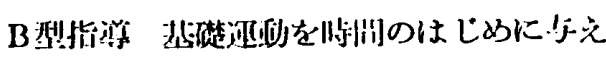

$$
\text { た㭶令 }
$$

\section{指䔔の結果}

A 些指i?

可可师さが多い。

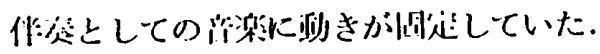

激きにらつるまでに沵间がかっった。

B 犁指致

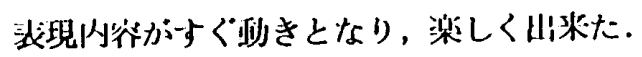

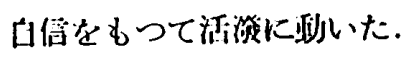

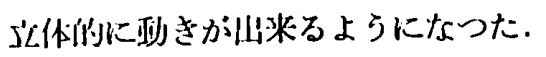

畍きがリズムにのろうとしだした。

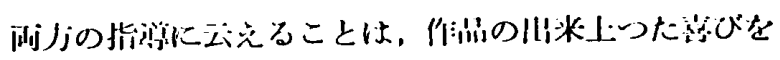
味わつた。 